\title{
PENGARUH POLA ASUH ORANG TUA TERHADAP PERILAKU ANAK DALAM DRAMA KOREA SKY CASTLE
}

\author{
Oleh: \\ Fauziyah \\ Email: fauziyah3009@gmail.com \\ Program Studi Psikologi Fakultas Kedokteran Universitas Lambung Mangkurat
}

\begin{abstract}
Abstrak. Pola asuh merupakan suatu pola interaksi antara orang tua dan anak yang bersifat relatif konsisten dan tiap orang tua memiliki pola asuh yang berbeda. Lingkungan keluarga merupakan salah satu faktor yang dapat membentuk perilaku seseorang. Berpengaruhnya pola asuh orang tua terhadap perilaku anak digambarkan dengan baik pada drama Korea Sky Castle. Drama Korea Sky Castle mengisahkan tentang orang tua yang terobsesi ingin menyekolahkan anak mereka ke universitas bergengsi demi mempertahankan status sosialnya. Dengan menggunakan metode penelitian kajian literatur, penelitian ini bertujuan untuk mengetahui bagaimana perilaku anak-anak yang dibesarkan dengan pola asuh tertentu dalam drama Korea Sky Castle.
\end{abstract}

Keywords: Pola asuh; perilaku anak; drama Korea

\section{PENDAHULUAN}

Di masa pandemi seperti sekarang ini, drama Korea makin marak digemari oleh masyarakat dari berbagai kalangan dan usia yang disebabkan oleh keharusan tinggal di rumah ketika tidak ada keperluan sebagai pencegahan penyebaran virus COVID-19. Pada era globalisasi ini semakin banyak teknologi yang berkembang untuk mendapatkan informasi-informasi dengan cara beragam, mulai dari informasi audio maupun visual. Terdapat beragam bentuk penyampaian informasi, salah satunya ialah tayangan drama yang menjadi media bagi masyarakat untuk mengetahui informasi yang sedang digandrungi pada zamannya. Salah satu jenis tayangan drama adalah tayangan drama korea, yang mana para pemain hingga gaya berpakaiannya banyak digemari oleh masyarakat (1). Sejak tahun 2002, momen Piala Dunia Korea Selatan dan Jepang digunakan untuk memperkenalkan drama seri Korea Selatan oleh stasiun televisi Indonesia. Pada 26 Maret 2002, Trans TV pertama kali menayangkan drama Korea berjudul Mother's Sea di Indonesia (2). Hingga saat ini, penayangan drama Korea di stasiun TV Indonesia terus dilaksanakan karena mendapat minat masyarakat Indonesia. Dengan beragam jenis genre dan alur cerita yang unik, drama Korea memiliki banyak pilihan untuk ditonton. Namun, dari beragam pilihan tersebut, ada baiknya menonton drama Korea yang bukan hanya bermanfaat sebagai hiburan, tetapi juga untuk dimaknai. Salah satu drama Korea yang memiliki makna yang bagus adalah Sky Castle. Drama Korea Sky Castle sendiri cocok untuk ditonton bersama keluarga karena mengandung makna yang dalam dan dapat diambil pelajaran dari jalan ceritanya.

Sky Castle adalah drama Korea karya Yoo Hyun Mi yang ditayangkan di stasiun TV swasta Korea JTBC pada tahun 2018 hingga 2019. Drama Korea Sky Castle menceritakan kisah tentang orangtua yang merupakan alumni dari universitas-universitas SKY dan hanya ingin menyekolahkan anak mereka di universitas-universitas SKY (3). Kata "SKY" diambil dari inisial tiga universitas paling bergengsi di negeri ginseng tersebut, yaitu Universitas Nasional Seoul, Universitas Korea, dan Universitas Yonsei.

Drama ini mengambil tema tentang kehidupan kaum elite Korea yang berkompetisi dan terobsesi untuk memasukkan anaknya ke universitas bergengsi di Korea Selatan untuk menjaga dan menaikkan status sosialnya. Masyarakat Korea Selatan memang mementingkan pendidikan, sehingga untuk masuk ke universitasnya pun harus melewati seleksi yang ketat. Tidak sedikit orangtua yang berkeinginan kuat hingga terkesan memaksa anaknya untuk masuk ke universitas ternama di Korea Selatan. "SKY" menjadi kata yang populer bagi masyarakat Korea Selatan. Dari judulnya yang menggunakan kata "SKY", 
drama Korea Sky Castle ini menceritakan kisah tentang keluarga yang tinggal di perumahan elite bernama Sky Castle. Karena kedudukan status sosialnya, orang tua yang tinggal di perumahan elite tersebut sangat mementingkan prestasi akademik anak-anaknya hingga terkesan mengagungkan dan mengenyampingkan perasaan dan kondisi mental anak mereka. Pola asuh tersebut kemudian membentuk perilaku anak yang akan menjadi bumerang kepada orang tua itu sendiri.

Kisah Sky Castle bermula dari keluarga Lee Myung Joo yang anaknya berhasil masuk di pendidikan kedokteran di Universitas Nasional Seoul. Namun, Lee Myung Joo baru mengetahui kalau anaknya yang bernama Park Young Jae itu tidak mengambil kesempatan tersebut karena ia tidak berminat untuk menjadi dokter. Dan hal tersebut menyebabkan petaka bagi keluarga mereka.

Di sisi lain, Han Seo Jin yang merupakan salah satu ibu penghuni Sky Castle mendapat tekanan dari mertuanya yang ingin menjadikan keluarganya sebagai keluarga dokter tiga generasi kemudian bertekad untuk membuktikan kemampuannya dengan cara mengabulkan keinginan mertuanya tersebut. Han Seo Jin memiliki dua orang putri yang memiliki sifat bertolak belakang, yaitu Kang Ye Suh dan Kang Ye Bin.

Obsesi terhadap prestasi akademik anak juga dirasakan oleh keluarga Cha Min Hyuk yang bekerja sebagai profesor jurusan Hukum dan mantan jaksa. Cha Min Hyuk memiliki seorang putri bernama Cha Se Ri yang menjadi kebanggaannya karena berhasil menjadi mahasiswi Universitas Harvard dan anak kembar laki-laki bernama Cha Seo Joon dan Cha Ki Joon yang masih duduk di bangku SMA. Cha Min Hyuk terus berusaha sekuatnya agar anaknya dapat berada di "puncak piramida" seperti apa yang ia impikan dan terus menanamkan gagasan "siapapun adalah saingan" meskipun itu adalah saudara sendiri. Meski memiliki ayah tergolong keras, anak-anak Cha Min Hyuk memiliki ibu yang selalu melindungi mereka dan menjadi sumber kekuatan mereka untuk menjalani kehidupan yang mereka inginkan.

Penghuni lain Sky Castle ialah keluarga Jin Jin Hee yang memiliki seorang anak laki-laki yang sangat mereka sayangi. Pada awal cerita
Jin Jin Hee sempat menekan anaknya yang bernama Woo Soo Han untuk mendapat nilai tinggi dan masuk sekolah kedokteran, tetapi ia berhenti melakukan hal tersebut karena Woo Soo Han memutuskan untuk pergi dari rumah karena tidak tahan dengan tuntutan orang tuanya tersebut.

Dan yang terakhir ada keluarga Lee Soo Im yang merupakan penghuni baru yang tinggal di rumah yang dulu ditempati keluarga Lee Myung Joo. Lee Soo Im yang merupakan ibu tiri dapat memiliki hubungan yang erat dengan anak tirinya karena sifatnya yang pengertian dan selalu mendukungnya. Lee Soo Im dan suaminya mengasuh anaknya dengan sangat baik yang kemudian menjadikan anaknya yang bernama Hwang Woo Joo sebagai pribadi yang cerdas dan percaya diri.

Masithah dkk. (2005) mengungkapkan bahwa perkembangan anak merupakan proses yang kompleks, terbentuk dari keterkaitan lingkungan sekitar dan potensi diri anak. Lingkungan keluarga adalah lingkungan pertama dan utama yang berpengaruh terhadap perkembangan anak, karena sosok yang paling berperan adalah orang tua. Kondisi lingkungan keluarga yang kondusif bagi kecenderungan tingkah laku melindungi dan mensejahterakan anak harus mampu diciptakan oleh orang tua. Subekti dkk. (2008) mengungkapkan bahwa pola asuh ialah pola interaksi antara orang tua dan anak, yaitu suatu cara sikap atau perilaku orang tua saat berinteraksi dengan anak, termasuk cara penerapan aturan, mengajar nilai atau norma, memberikan perintah dan kasih sayang serta menunjukkan sikap dan perilaku baik sehingga dijadikan panutan bagi anaknya (4).

Menurut Petranto (Suarsini, 2013) pola asuh orang tua adalah pola perilaku yang diterapkan pada anak yang bersifat relatif konsisten dari waktu ke waktu. Pola perilaku ini memiliki segi negatif dan positif yang dirasakan oleh anak. Tiap keluarga menanamkan pola asuh yang berbeda, hal ini tergantung persepsi dari tiap orang tua (5).

Secara teoritis, terdapat 3 jenis pola asuh yang dilakukan orang tua, yaitu pola asuh otoriter, permisif, dan otoritatif. Pola asuh otoriter merupakan pola asuh dimana orang tua menuntut secara berlebihan serta sangat kurang responsif dan kurang menanggapi apa yang 
anak inginkan. Pola asuh permisif adalah pola asuh yang tidak melibatkan orang tua dalam kehidupan anak. Dan pola asuh otoritatif merupakan pola asuh yang mendorong anak agar mandiri dan masih menetapkan batasan dan pengendalian atas tindakan mereka sendiri (6).

Perkembangan sosial dan moral yang akan membentuk watak, sifat, dan sikap nantinya dipengaruhi oleh perlakuan yang didapat anak dari orang tuanya sejak masa kecil (6). Pembentukkan karakter anak dapat dipengaruhi oleh pola asuh orang tua (7). Masing-masing pola asuh yang orang tua terapkan akan membentuk beragam bentuk perilaku pada anak (8). Oleh karena itu, anak harus mendapat perlakuan yang baik dan sesuai agar perilaku yang akan terbentuk searah dengan nilai dan norma sosial dan moral di masyarakat serta tidak memiliki perilaku negatif yang menyimpang.

Mengutip dari buku Menulis di Kala Badai Covid-19, terdapat satu kalimat yang menginspirasi penulis, yaitu "menulis hal-hal baik, menulis yang bermanfaat, menulis perihal kebaikan, bukan untuk diri sendiri, tetapi untuk pembaca" (9). Berdasarkan hal tersebut, penulis ingin memberikan sebuah tulisan yang bermanfaat bagi pembaca dan memutuskan untuk menjabarkan salah satu hal yang dapat dimaknai dari drama Korea Sky Castle, yaitu pengaruh pola asuh orang tua terhadap perilaku anak, dengan tujuan untuk mengetahui beragam perilaku anak yang terbentuk dari macammacam pola asuh yang berbeda.

\section{METODE PENELITIAN}

Metode penelitian yang digunakan dalam penelitian ini adalah kajian literatur, yaitu dengan cara meneliti dan memahami buku-buku, jurnal, atau hasil penelitian yang berkaitan dengan topik penelitian. Berikut literatur yang menjadi acuan dalam penelitian ini. Yang pertama adalah jurnal pendidikan Universitas Garut tahun 2017 berjudul Pola Asuh Orang Tua dan Implikasinya Terhadap Pembentukan Karakter Anak yang ditulis oleh Ani Siti Anisah. Berdasarkan jurnal ini dapat diketahui bahwa pola asuh orang tua memiliki keterlibatan terhadap kepribadian anak dan karakter akan dimunculkan oleh kepribadian ketika ada faktor yang mempengaruhi. Jika dibandingkan dengan penelitian penulis, terdapat perbedaan dan persamaan pada penelitian ini. Perbedaannya terdapat pada fokus masalah yang diambil oleh penulis, fokus masalah pada penelitian ini adalah membahas tentang keterkaitan antara pola asuh orang tua terhadap karakter anak pada umumnya. Sedangkan penelitian yang dilakukan penulis adalah pengaruh pola asuh orang tua terhadap perilaku anak dalam drama Korea Sky Castle. Persamaan yang ditemukan dalam penelitian ini adalah sama-sama melakukan penelitian yang mengkaji tentang pola asuh orang tua.

$\begin{array}{cc} & \text { Yang kedua adalah hasil penelitian dari } \\ \text { dosen Fakultas Kedokteran Universitas }\end{array}$ Lambung Mangkurat tahun 2013, yaitu Atik Cimi, Neka Erlyani, dan Devi Rahmayanti yang berjudul Pola Asuh Orang Tua dengan Kepercayaan Diri Anak. Metode yang digunakan dalam penelitian ini adalah deskriptif analitin dengan pendekatan Cross-sectional dengan populasi orang tua siswa di Taman Kanak-Kanak Putra 1 Banjarbaru berjumlah 40 responden. Penelitian ini membahas tentang hubungan pola asuh orang tua dengan kepercayaan diri anak. Hasil penelitian menunjukkan bahwa tidak ada korelasi antara pola asuh orang tua dengan kepercayaan diri anak yang disebabkan karena usia anak yang masih tergolong sangat muda. Jika dibandingkan dengan penelitian penulis, terdapat perbedaan dan persamaan pada penelitian ini. Perbedaannya terdapat pada fokus masalah yang diambil oleh penulis, fokus masalah pada penelitian ini adalah membahas tentang hubungan pola asuh orang tua dengan kepercayaan diri anak Sedangkan penelitian yang dilakukan penulis adalah pengaruh pola asuh orang tua terhadap perilaku anak dalam drama Korea Sky Castle. Persamaan yang ditemukan dalam penelitian ini adalah samasama melakukan penelitian yang mengkaji tentang pola asuh orang tua.

Yang ketiga, penelitian dari mahasiswi D3 Akademi Bahasa Asing Nasional Program Studi Bahasa Korea bernama Diah Ridani Harahap pada tahun 2019 yang berjudul Sisi Lain Sistem Pendidikan Korea Selatan dalam Drama Sky Castle. Metode yang digunakan dalam penelitian ini adalah deskriptif-kualitatif. Penelitian ini membahas tentang dampak negatif dari sistem pendidikan Korea Selatan pada drama Korea Sky Castle. Hasil peneltian ini mengungkapkan bahwa pola asuh orang tua yang keliru, gagasan negatif guru yang 
ditanamkan kepada siswa, tindakan bunuh diri dan pembunuhan, rasa iri, dan kecurangan yang dilakukan guru untuk meluluskan siswanya merupakan dampak negatif sistem pendidikan Korea Selatan yang ada pada drama Sky Castle. Perbedaannya terdapat pada fokus masalah yang diambil oleh penulis, fokus masalah pada penelitian ini adalah membahas tentang keterkaitan antara pola asuh orang tua terhadap karakter anak pada umumnya. Sedangkan penelitian yang dilakukan penulis adalah pengaruh pola asuh orang tua terhadap perilaku anak dalam drama Korea Sky Castle. Jika dibandingkan dengan penelitian penulis, terdapat perbedaan dan persamaan pada penelitian ini. Perbedaannya terdapat pada fokus masalah yang diambil oleh penulis, fokus masalah pada penelitian ini adalah membahas tentang sistem pendidikan di Korea Selatan Sedangkan penelitian yang dilakukan penulis adalah tentang pola asuh orang tua dan perilaku anak. Persamaan yang ditemukan dalam penelitian ini adalah sama-sama melakukan penelitian yang mengkaji tentang drama Korea Sky Castle.

\section{PEMBAHASAN}

Keluarga Lee Myung Joo dan Cha Min Hyuk dalam drama Korea Sky Castle ini menerapkan pola asuh otoriter yang hanya melakukan komunikasi secara searah. Dalam pola asuh otoriter, orang tua memaksakan kehendak dan suatu peraturan harus ditaati oleh anak (6). Berdasarkan hasil penelitian Atik Cimi dkk. pada tahun 2013 yang berjudul "Pola Asuh Orang Tua Dengan Kepercayaan Diri Anak" diperoleh data bahwa sebanyak 87,5\% responden yang merupakan ibu murid Taman Kanak-Kanan Putra 1 Banjarbatu menerapkan pola asuh otoriter (6). Hal ini membuktikan bahwa masih banyak orang tua yang menerapkan pola asuh otoriter pada anaknya. Gambaran pola asuh otoriter dalam keluarga Lee Myung Joo dapat dilihat pada perlakuan orang tua Park Young Jae yang ia tuliskan pada tablet digital yang sengaja ia tinggalkan sebelum pergi meninggalkan rumah. Di tablet itu ia menuliskan bahwa sejak usia 7 tahun orang tuanya telah memaksakanya untuk terus belajar bahkan ketika kondisi kesehatannya memburuk hingga pingsan, orang tuanya tetap memaksanya untuk belajar dan ibunya tidak akan memberinya makanan jika ia tidak mendapatkan peringkat pertama di kelasnya.
Tekanan yang diberikan orang tua menyebabkan Park Young Jae mengalami stres akademik. Heiman \& Kariv (2005) mengungkapkan bahwa stres akademik merupakan stres yang disebabkan oleh sumber stres dalam kegiatan belajar, seperti tekanan menghadapi kenaikan kelas, kecemasan ketika melaksanakan ujian, tugas yang menumpuk, tidak mendapat nilai yang baik, menentukan jurusan kuliah dan karir masa depan, serta memanajemen waktu (10). Ni'maruzahroh \& Adawiyah (2016) mengungkapkan bahwa dalam proses pendidikan, beban belajar dan beragam jenis ruang lingkup sosial dapat mengakibatkan stres akademik pada siswa yang kemudian akan memberi dampak pada nilai akademik siswa dan adaptasi sosial siswa (10). Dari tekanan yang diterima, Park Young Jae pun sempat berpikir untuk menyakiti dirinya sendiri hingga bunuh diri. Namun kemudian, Park Young Jae memutuskan untuk balas dendam kepada orang tuanya dengan cara meninggalkan mereka ketika sedang merasa bahagia, yaitu ketika Park Young Jae berhasil masuk sekolah kedokteran. Rencananya tersebut membulat setelah terjadi pertengkaran besar antara dirinya dengan orang tuanya yang menyebabkan ayahnya marah besar karena pemberontakan dan pengungkapan Park Young Jae tentang dirinya yang sudah tidak sanggup untuk hidup di rumah bersama orang tuanya dan menuruti kemauan orang tuanya. Keputusan sosial seseorang sangat dipengaruhi oleh emosi individu tersebut (11) dan karena emosi yang dirasakan inilah yang menyebabkan ayah Park Young Jae ingin menembakkan pistol berburunya ke arah Park Young Jae tetapi berhasil ditahan oleh Lee Myung Jae dan kejadian tersebut memperparah kondisi mental Park Young Jae yang tertekan dan depresi.

Segala tuntutan dan paksaan yang dilakukan orang tua Park Young Jae ini dilatar belakangi oleh keinginan mereka untuk menjadikan Park Young Jae sebagai dokter yang ketika itu terjadi, menjadikan keluarganya sebagai dokter 3 generasi. Selain itu, Park Young Jae juga dilarang oleh ibunya untuk memiliki hubungan dengan anak dari pengasuhnya, yang disebabkan hal tersebut dapat merusak citra keluarga mereka yang merupakan keluarga kaya raya dengan latar belakang luar biasa. Bukannya memberi ketenangan dan rasa aman pada anak yang tertekan, Lee Myung Jae tetap membahas 
tentang universitas dan menjadi dokter di saat anak memberontak karena tidak tahan dengan tuntutannya. Hal tersebut mempresentasikan pola asuh otoriter, dimana pendapat anak tidak didengar dan orang tua tetap egois pada anak mereka.

Dari keluarga Lee Myung Joo ini dapat dilihat bagaimana perilaku yang dilakukan Park Young Jae yang merupakan pengaruh dari pola asuh otoriter orang tuanya. Park Young Jae dibatasi dengan ketat oleh orang tuanya, harus menuruti apa yang dikatakan orang tua, serta ia tidak dapat mengungkapkan pendapat dan perasaannya kepada orang tuanya. Rasa takut untuk mengungkapkan perasaannya kepada orang tuanya menyebabkan penumpukkan rasa marah dan kesal yang ketika tumpukkan tersebut meledak akan memberikan dampak yang besar, baik itu kepada diri sendiri maupun orang lain. Begitulah Park Young Jae yang menumpuk rasa stres dan frustasinya yang kemudian menyebabkannya melakukan perilaku negatif seperti percobaan bunuh diri, melakukan kebohongan besar, dan memutuskan hubungan dengan orang tua.

Pola asuh otoriter juga diterapkan pada keluarga Cha Min Hyuk. Cha Min Hyuk yang merupakan dosen besar di universitas ternama menetapkan standar tinggi kepada anakanaknya, yaitu puncak piramida yang berarti posisi paling tinggi di antara semua orang. Cha Min Hyuk rutin mendidik anak-anaknya di ruangan khusus yang kedap suara dan kedap cahaya di rumahnya. Di ruang belajar tersebut, anak-anaknya diminta untuk belajar dan menyelesaikan soal yang ia berikan dengan benar dan tepat waktu, mereka akan dimarahi bahkan dipukul jika salah menjawab soal yang diberikan. Cha Seo Joon dan Cha Ki Joon yang duduk di bangku sekolah yang sama dengan Kang Ye Suh pun makin mendapat tekanan oleh ayahnya untuk mendapat nilai sempurna dan lebih tinggi dari Kang Ye Suh. Cha Min Hyuk menanamkan konsep "semua orang adalah saingan" dalam mendidik anak-anaknya dan bahkan meminta Cha Seo Joon dan Cha Ki Joon berkompetisi meski mereka adalah saudara.

(Lamb, 2010) Keterlibatan ayah dalam pengasuhan anak merupakan keikutsertaan yang bersifat positif dalam berinteraksi langsung dengan anak, memberikan kehangatan, melakukan pengawasan, mengontrol kegiatan anak, serta melakukan tanggung jawab terhadap keperluan dan kebutuhan anak (12). Meski Cha Min Hyuk telah bersedia terlibat dalam mengasuh anak-anaknya, ia melakukannya dengan cara yang keliru. Seperti yang Dagun (2013) ungkapkan, ketika ayah bisa berperan aktif dalam proses belajar anak, maka kemampuan anak dalam bidang akademik akan cenderung tinggi. Tetapi ketika ayah menekan anak untuk memiliki prestasi akademik, maka kemampuan dan pencapaian anak di bidang akademik akan cenderung rendah (12). Secara sadar atau tidak sadar, anak akan meresapi sikap, perilaku, dan kebiasaan orang tua yang selalu dilihat, dinilai, dan diritu olehnya yang kemudian akan menjadi kebiasaan (13). Pernyataan tersebut sejalan dengan perilaku Cha Ki Joon yang menjadi malas untuk belajar di sekolah dan kasar serta berani berteriak pada orang tuanya. Perilakunya tersebut bersumber dari perilaku ayahnya yang sering ia lihat sejak kecil.

Salah satu perilaku negatif yang dapat terbentuk dari pola asuh otoriter adalah keberanian anak untuk berbohong dengan kedua orang tuanya. Cha $\mathrm{Se} \mathrm{Ri}$, putri kebanggaan Cha Min Hyuk yang berhasil masuk Universitas Harvard ternyata telah menipunya selama berbulan-bulan. Cha Se Ri melakukan tindakan kriminal dengan berpurapura menjadi mahasiswi Universitas Harvard dan menggunakan uang yang selalu dikirim orang tuanya untuk berfoya-foya. Ia mengaku nekat berbohong karena ingin ayahnya bahagia dan khawatir ayahnya kecewa terhadap dirinya karena tidak berhasil menjalani kehidupan yang diinginkan oleh ayahnya. Cha Se Ri juga mengatakan bahwa karena ketidakpuasan ayahnya terhadap dirinyalah yang menjadi penyebab lain dirinya nekat berbohong.

Dari pernyataan Cha Se Ri tersebut, bisa dilihat bahwa persepsi orangtua terhadap anak memiliki pengaruh yang besar dalam keputusan yang akan anak ambil. Perasaan hangat pada anak bisa didapatkan dari lingkungan keluarga yang selalu mendukungnya (14). Perasaan hangat itulah yang dicari oleh Cha Se Ri. Cha Min Hyuk memperlakukannya dengan berbeda setelah Cha $\mathrm{Se} \mathrm{Ri}$ menjadi mahasiswi Universitas Harvard. Perilaku negatif yang anak lakukan dapat menjadi caranya untuk memperoleh apa yang sebelumnya belum pernah ia dapat dari orangtuanya. 
Dalam perkembangan anak, selain peran pengasuhan ayah, peran pengasuhan ibu juga diperlukan karena ayah dan ibu memiliki peran pengasuhan yang berbeda (12). Ibu dalam keluarga Cha Min Hyuk ini berperan besar dalam menguatkan, mendukung, dan melindungi anak-anaknya. Sumber kekuatan anak-anaknya untuk menjalani kehidupan yang mereka inginkan ialah ibu mereka. Pola asuh demokratis yang diterapkan istri Cha Min Hyuk dalam mengasuh anak-anaknya memberikan rasa nyaman kepada ketiga anaknya. Mereka pun menjadi lebih dekat dengan ibu daripada ayah karena dukungan yang diberikan oleh ibunya. Dukungan orang tua ialah sesuatu yang diperoleh anak dari orang tua berupa pemenuhan kebutuhan pokok anak seperti perhatian, rasa aman, sarana dan prasarana untuk mendukung tumbuh kembang emosional anak (15). Cha Se Ri yang pada awalnya hanya dapat mengubur mimpinya pun menjadi percaya diri untuk menggapai mimpinya menjadi pengusaha karena ibunya yang terus mendukung cita-citanya.

Dukungan dari orang tua juga diberikan Han Seo Jin sebagai ibu yang selalu memfasilitasi pendidikan Kang Ye Suh dan selalu mendukung serta memberi perhatian lebih kepadanya. Pola asuh yang diterapkan Han Seo Jin menggambarkan pola asuh permisif. Kebebasan anak yang tanpa batas untuk berperilaku sesuai keinginannya menjadi tanda pola asuh permisif (16). Han Seo Jin memanjakan anaknya dengan selalu menuruti apa yang Kang Ye Suh inginkan, termasuk mempekerjakan kembali guru les yang ia pecat setelah mengetahui kalau guru les itulah yang secara tidak langsung menghasut Park Young Jae untuk balas dendam kepada orang tuanya melalui cerita dongeng yang menekankan nilai negatif. Guru tahu betul bahwa pesan yang terkandung dalam cerita yang dibawakannya akan tersimpan dalam memori anak seandainya anak tersebut berada dalam situasi yang sama dengan cerita tersebut (17). Hal ini menunjukkan bahwa selain keluarga, guru yang merupakan orang tua kedua anak juga dapat mempengaruhi perilaku anak.

Pengasuhan Han Seo Jin tersebut kemudian menjadikan Kang Ye Suh menjadi pribadi yang memiliki perilaku angkuh, sombong, dan kurang sopan tetapi ia juga memiliki prestasi akademik yang baik. Siswa yang memiliki prestasi baik di bidang akademik memiliki jadwal belajar rutin tersendiri setiap harinya (18). Kegiatan rutin belajar tersebut tergambar pada perilaku rajin belajar yang dimiliki Kang Ye Suh. Siswa dapat mengalami kesulitan dalam proses belajar jika keadaan lingkugannya kurang mendukung (19). Pernyataan tersebut sesuai dengan Kang Ye Suh yang juga menata kamarnya sebaik mungkin untukvmendukung kegiatan belajarnya.

Di sisi lain, Kang Ye Bin, putri bungsu Han Seo Jin tidak mendapat perlakuan yang sama. Kang Ye Bin jarang diperhatikan orang tuanya karena mereka selalu berfokus pada Kang Ye Suh yang memiliki prestasi luar biasa dalam bidang akademik, dimana hal tersebut berkebalikan dengannya yang tidak terlalu memikirkan pelajaran. Meskipun terlihat biasa saja dengan perbedaan perlakuan orang tuanya kepada dirinya dan kakaknya, sebenarnya Kang Ye Bin merasa iri dengan hal tersebut. Ia kemudian mencuri di toko swalayan untuk bersenang-senang dengan teman-temannya. Tanpa sadar, perilaku menyimpang ini ia lakukan untuk menarik perhatian orang tuanya yang jarang memperhatikannya. Namun, perilaku mencuri yang dilakukan Kang Ye Bin malah ditutupi dan diwajarkan oleh Han Seo Jin, ia berkata kepada pemilik toko swalayan tersebut bahwa anaknya melakukan tersebut karena stres belajar.

Pola asuh permisif yang selalu menuruti keinginan anak dan menetapkan batasan yang sedikit ini dapat membentuk perilaku buruk pada anak. Anak menjadi kurang mengetahui mengenai hal-hal apa saja yang seharusnya tidak ia lakukan karena orangtua yang terus mewajarkannya dan tidak memberitahunya bahwa perilakunya merupakan perilaku yang menyimpang (16). Han Seo Jin yang selalu melindungi dan tidak memberi pelajaran pada anak ketika mereka melakukan kesalahan membentuk perilaku buruk pada anak. Han Seo Jin melakukan hal tersebut karena ingin anaknya tidak memiliki masalah dan sukses di masa depan, namun sebenarnya akibat dari pola asuh yang diterapkan ini malah akan membuat anak melakukan segala hal yang mereka inginkan termasuk tindakan kriminal tanpa tahu itu salah atau benar karena tidak pernah diberi standar atau batasan yang jelas. Anak yang diasuh menggunakan pola asuh permisif ini tidak pernah belajar mengendalikan perilakunya dan selalu ingin mendapat permintaannya (20). 
Pola asuh yang memberi batasan atau standar yang jelas ialah pola asuh otoritatif yang diterapkan keluarga Lee Soo Im. Santrock (1995) mengungkapkan bahwa pola asuh otoritatif merupakan pola asuh yang mendorong anak untuk menjadi mandiri tetapi tetap menetapkan kontrol atau batasan atas tindakan mereka (7). Lee Soo Im dan suaminya membesarkan anak mereka dengan membebaskan anak untuk mengambil keputusan sendiri, namun tetap melakukan pengendalian yang wajar untuk mengontrol perilaku anaknya. Anak mereka, Hwang Woo Joo yang pada awalnya memiliki perilaku kasar pada Lee Soo Im yang merupakan ibu sambungnya dapat merubah perilaku tersebut dan menjadi lebih dekat kepada ibunya. Lee Soo Im yang bersikap perhatian dan hangat pada Hwang Woo Joo, berhasil membuatnya menjadi ibu sambung yang berbeda dari pandangan orang lain mengenai ibu tiri yang kejam dan kasar.

Dibesarkan dalam keluarga yang menerapkan pola asuh otoritatif membentuk perilaku positif pada Hwang Woo Joo. Ia menjadi anak yang percaya diri, cerdas, dan sopan. Ia juga selalu rajin belajar hingga mencapai prestasi akademik yang baik meskipun orang tuanya tidak pernah menyuruhnya untuk belajar. Mayangsari (2005) mengungkapkan bahwa dorongan positif bagi anak untuk menggapai prestasi dapat ditumbuhkan melalui sikap dan penerimaan positif dari orang tua dalam pola asuhnya, karena dengan orang tua yang memiliki sifat penerimaan positif akan selalu mengasihi dan memperhatikan anaknya secara penuh, pola asuhnya pun akan penuh dengan kebahagiaan, perasaan berharga dan rasa dilindungi, kepercayaan, memiliki ikatan komunikasi yang baik, serta keterlibatan bersama dalam keseharian maupun dalam bidang akademis (21). Dorongan positif inilah yang membentuk perilaku anak sehingga ia tidak hanya cerdas dalam akademik, tetapi juga cerdas dalam kesehariannya.

Dorongan positif tersebut juga diberikan Jin Jin Hee dan suaminya kepada anak tunggal mereka, Woo Soo Han. Meski di awal cerita Jin Jin Hee sempat menerapkan pola asuh otoriter, ia kemudian menggantinya dengan pola asuh otoritatif karena Woo Soo Han pernah pergi dari rumah yang disebabkan oleh rasa tertekan yang diperoleh dari pola asuh otoriter tersebut. Dari kejadian tersebut, Jin Jin Hee menyadari bahwa pola asuh yang telah ia terapkan selama ini tidak membuat anaknya bahagia. Sejak saat itu, ia menjadi lebih hangat dan membebaskan anaknya untuk berbuat sesuai keinginannya, namun tetap ada batasan yang tidak boleh dilewati. Perubahan pola asuh ini juga berdampak pada perilaku anak. Woo Soo Han yang sebelumnya sering takut, cemas, dan tidak percaya diri pun menjadi anak yang lebih ceria dan bahagia.

Lee Soo Im pada akhirnya mengetahui cerita mengenai rumah yang baru ditinggalinya tersebut. Sebagai seorang ibu yang menentang pola asuh otoriter, Lee Soo Im pun berusaha keras untuk menggali informasi tentang keluarga Lee Myung Joo. Dikutip dari buku Menulis Mudah, Menulis Ala Ersis Writing Theory, "menulis merupakan sarana untuk mengabadikan pendapat, ide, gagasan, dan lain sebagainya" (22). Itulah yang dilakukan oleh Lee Soo Im yang merupakan penulis buku. Ia menerbitkan buku mengenai perumahan Sky Castle agar kejadian yang terjadi pada keluarga Lee Myung Joo tidak diulang oleh keluarga lain serta agar orang lain dapat dapat mengambil pelajaran dan memaknai kejadian tidak mengenakkan yang terjadi pada keluargakeluarga yang menerapkan pola asuh dengan keliru.

Pembentukkan dan perubahan perilaku anak sangat berkaitan dengan pola asuh orang tua. Orang tua tidak bisa terlalu memaksakan kehendak mereka dengan alasan mereka peduli dan ingin yang terbaik untuk anak-anak mereka. Padahal mereka sendirilah yang telah menjadikan anak mereka sebagai alat untuk meraih keinginan mereka. Anak yang merupakan anugerah dari Tuhan sudah seharusnya diperlakukan dengan baik, sehingga ia dapat menjadi pribadi yang positif dan bermanfaat, baik untuk dirinya maupun orang lain.

Dari drama Korea Sky Castle ini, dapat diketahui bahwa kehidupan sosial seseorang juga mempengaruhi pola asuhnya. Hampir seluruh keluarga di drama Korea Sky Castle ini sangat mementingkan status dan kedudukan sosial serta citra keluarganya. Cara mereka untuk menjaga kedudukan status sosial mereka ialah dengan kesuksesan anak-anak mereka dan anggapan mereka tentang kesuksesan seseorang yaitu berhasil menuntut ilmu di universitas 
ternama. Berdasarkan hasil penelitian Harahap (2019), dalam drama Korea Sky Castle diperoleh hasil analisa mengenai dampak negatif sistem pendidikan Korea Selatan dan beberapa di antara hasil tersebut terdapat dampak negatif berupa obsesi suami Lee Myung Joo untuk menjadikan Park Young Jae sebagai dokter generasi ketiga dan Cha Min Hyuk yang menanamkan konsep "siapapun adalah saingan" pada anak-anaknya (23). Hasil penelitian tersebut merupakan contoh pola asuh orang tua yang berpengaruh terhadap perilaku anak. Dari penelitian tersebut dapat ditarik kesimpulan bahwa sistem pendidikan dapat mempengaruhi pola asuh orang tua.

Hal tersebutlah yang menjadikan mereka menerapkan pola asuh tertentu untuk mendidik anak-anak mereka. Sedangkan anak mereka, mengalami kesulitan dalam kehidupan sosialnya karena terus merasa cemas, takut, dan bahkan dijauhi teman sebayanya karena yang terus mereka pikirkan adalah kemungkinan terburuk yang akan terjadi jika mereka tidak berhasil mengikuti keinginan orang tuanya. Dan anak yang dibesarkan dengan pola asuh yang baik akan menikmati hidupnya dengan bahagia dan rasa puas karena mereka bebas untuk mengeksplor dirinya tanpa melupakan batasanbatasan. Mereka juga akan merasa aman karena mengetahui mana yang salah dan mana yang baik, sehingga mereka dapat mengontrol diri mereka sendiri untuk tidak melakukan perilaku dan tindakan buruk. Hal-hal tersebutlah yang dapat membuat anak menjadi bersemangat dan penuh motivasi untuk mencapai kesuksesan yang mereka impikan.

\section{SIMPULAN}

Sky Castle merupakan drama Korea karya Yoon Hyun Mi yang tayang di stasiun televisi swasta JTBC pada tahun 2018 hingga 2019. Sky Castle menceritakan tentang kehidupan kaum elite Korea yang berkompetisi dan terobsesi untuk memasukkan anaknya ke universitas bergengsi di Korea Selatan untuk menjaga dan menaikkan status sosialnya. Secara teoritis, terdapat 3 jenis pola asuh yang dilakukan orang tua, yaitu pola asuh otoriter, permisif, dan otoritatif. Pola asuh otoriter merupakan pola asuh dimana orang tua menuntut secara berlebihan serta sangat kurang responsif dan kurang menanggapi apa yang anak inginkan. Pola asuh permisif adalah pola asuh yang tidak melibatkan orang tua dalam kehidupan anak. Dan pola asuh otoritatif merupakan pola asuh yang mendorong anak agar mandiri dan masih menetapkan batasan dan pengendalian atas tindakan mereka sendiri Dari 5 keluarga yang diceritakan dalam serial drama Korea ini, 2 keluarga di antaranya menerapkan pola asuh otoriter, 2 keluarga lain menerapkan pola asuh otoritatif dan 1 keluarga menerapkan pola asuh permisif. Keluarga Lee Myung Joo dan Cha Min Hyuk yang menerapkan pola asuh otoriter membentuk perilaku anak yang cenderung negatif, sedangkan keluarga Lee Soo Im dan Jin Jin Hee yang menerapkan pola asuh otoritatif membentuk perilaku anak yang cenderung positif. Pembentukan perilaku negatif anak juga ditemui pada keluarga Han Seo Jin yang menerapkan pola asuh permisif. Dalam drama Korea Sky Castle ini juga ditemui perubahan perilaku anak yang terjadi karena perubahan penerapan pola asuh yang diterima anak. Hal tersebut membuktikan bahwa pola asuh orang tua memberi pengaruh yang signifikan pada perilaku anak.

\section{REFERENSI}

1. Apsari, L., Mayangsari, M. D., \& Erlyani, N. (2017). Pengaruh Perilaku Modeling pada Tayangan Drama Korea terhadap Citra Diri Remaja Penggemar Drama Korea. Jurnal Ecopsy, 3(3).

2. Putri, I. P., Liany, F. D. P., \& Nuraeni, R. (2019). K-Drama dan Penyebaran Korean Wave di Indonesia. ProTVF, 3(1), 68-80.

3. 한귀은. (2019). TV 드라마< SKY 캐슬> 에 나타난 욕망. 응시. 주체화. 국어교육, 165, 299-329.

4. Cimi, A., Erlyani, N., \& Rahmayanti, D. (2016). Pola Asuh Orang Tua Dengan Kepercayaan Diri Anak. Dunia Keperawatan: Jurnal Keperawatan dan Kesehatan, 1(1), 57-63.

5. Adawiah, R. (2017). Pola Asuh Orang Tua dan Implikasinya terhadap Pendidikan Anak: Studi pada Masyarakat Dayak di Kecamatan Halong Kabupaten Balangan. Jurnal Pendidikan Kewarganegaraan, 7(1), 33-48.

6. Anisah, A. S. (2017). Pola asuh orang tua dan implikasinya terhadap pembentukan karakter anak. Jurnal Pendidikan UNIGA, 5(1), 70-84. 
7. Rokhmah, D. (2015). Pola asuh dan pembentukan perilaku seksual berisiko terhadap HIV/AIDS pada waria. KEMAS: Jurnal Kesehatan Masyarakat, 11(1), 125134.

8. Jannah, H. (2012). Bentuk pola asuh orang tua dalam menanamkan perilaku moral pada anak usia di kecamatan ampek angkek. Jurnal Ilmiah Pesona PAUD, 1(2).

9. Abbas, E. W., \& Erlyani, N. (2020). Menulis di Kala Badai Covid-19.

10. Kusuma, A. D., Rachmah, D. N., \& Dewi, R. S. (2020). PERBEDAAN STRES AKADEMIK PADA SISWA YANG BERSEKOLAH FULL DAY DAN YANG TIDAK FULL DAY DI MAN TANAH BUMBU DAN MAN 3 BANJARMASIN. Jurnal Kognisia: Jurnal Mahasiswa Psikologi Online, 1(1), 55-62.

11. Lestari, N., Erlyani, N., \& Mayangsari, M. D. (2020). EFEK INTERPERSONAL DARI EKSPRESI EMOSI MARAH TERHADAP PERILAKU PROSOSIAL PADA SISWA SEKOLAH MENENGAH ATAS DI KECAMATAN GAMBUT. Kognisia prodi Psikologi FK ULM, 2(2), 164-171.

12. Kemala, E., Safitri, J., \& Zwagery, R. V. (2020). HUBUNGAN ANTARA PERSEPSI KETERLIBATAN AYAH DALAM PENGASUHAN DENGAN FLOW AKADEMIK PADA PESERTA DIDIK KELAS IX SMP NEGERI 1 BANJARBARU. Kognisia prodi Psikologi FK ULM, 1(2), 60-64

13. Naviati, E. Hubungan Pola Asuh Otoritatif dengan Perkembangan Mental Emosional pada Anak Usia'Pra Sekolah di TK Melali Putih Banvumanik.

14. Saturrosidah, A., Mayangsari, M. D., \& Hidayatullah, M. S. (2020). PENGARUH KELEKATAN DENGAN ORANGTUA TERHADAP KECERDASAN ADVERSITAS PADA REMAJA KORBAN PERCERAIAN. Kognisia prodi Psikologi FK ULM, 1(2), 21-27.

15. Baiti, A. A., \& Munadi, S. (2014). Pengaruh pengalaman praktik, prestasi belajar dasar kejuruan dan dukungan orang tua terhadap kesiapan kerja siswa SMK. Jurnal Pendidikan Vokasi, 4(2).

16. Santosa, A. W. U., \& Marheni, A. (2013). Perbedaan kemandirian berdasarkan tipe pola asuh orang tua pada siswa SMP Negeri di Denpasar. Jurnal Psikologi Udayana, 1(1), 54-62.

17. Leza, N. M., Zwagery, R. V., \& Mayangsari, M. D. (2020). PERBEDAAN PERILAKU MENOLONG ANAK USIA DINI YANG DIBERIKAN METODE CERITA MORAL YANG MENEKANKAN EMOSI NEGATIF TOKOH DAN METODE CERITA NONMORAL. Kognisia prodi Psikologi FK ULM, 2(2), 87-94.

18. Sitanggang, N. G., Mayangsari, M. D., \& Zwagery, R. V. (2020). HUBUNGAN ANTARA PENETAPAN TUJUAN DENGAN MOTIVASI BERPRESTASI PADA SISWA SMK NEGERI 1 MARTAPURA. Kognisia prodi Psikologi FK ULM, 1(1), 17-22.

19. Primasari, L. E., Mayangsari, M. D., \& Zwagery, R. V. (2020). HUBUNGAN RESILIENSI DENGAN FLOW AKADEMIK PADA SISWA DI DAERAH LAHAN GAMBUT. Kognisia prodi Psikologi FK ULM, 2(1), 99-104.

20. Pravitasari, T. (2012). Pengaruh persepsi pola asuh permisif orang tua terhadap perilaku membolos. Educational Psychology Journal, 1(1).

21. Mayangsari, M. D. (2016). Motivasi Berprestasi Mahasiswa Ditinjau dari Penerimaan Orangtua. Jurnal Ecopsy, 1(1).

22. Abbas, E. W. (2020). Menulis Mudah, Menulis Ala Ersis Writing Theory.

23. Harahap, D. R. (2019). SISI LAIN SISTEM PENDIDIKAN KOREA SELATAN DALAM DRAMA SKY CASTLE (Doctoral dissertation, UNIVERSITAS NASIONAL). 